\title{
Biological, chemical and physical hazards control plans to ensure employees health during dried mango production
}

\author{
Alain Gustave YAGUIBOU ${ }^{1,2}$, Bakary TARNAGDA ${ }^{1,2}$, Souleymane ZIO ${ }^{2}$, Fulbert NIKIEMA ${ }^{3}$, François \\ TAPSOBA ${ }^{2}$, Jean Paul B. KARAMA ${ }^{1}$ and Aly SAVADOGO ${ }^{2}$ \\ ${ }^{1}$ Burkinabè Agency for Standardization Metrology and Quality, Department of Standardization and Certification, 01BP19 Ouagadougou 01, Burkina Faso \\ ${ }^{2}$ University Joseph KI-ZERBO, Department of Biochemistry and Microbiology, Laboratory of Applied Biochemistry and ImmunologY, 03 BP 7021 Ouagadougou 03, \\ Burkina Faso \\ ${ }^{3}$ National Public Health Laboratory, Quality Control and Applied Nutrition Department, og BP 24 Ouagadougou 09, Burkina Faso \\ Corresponding author's Email: alysavadogo@gmail.com; (DORCID: 0000-0002-9090-290X
}

\section{ABSTRACT}

Introduction. Food safety is an important quality approach that ensures the safety of both food products and the health of consumers and employees. Aim. This study aimed to develop a control plan through the analysis of critical points of the manufacturing process in the dried mango production units in Burkina Faso. Methods. Investigations were carried out within the manufacturing units located in two regions of Hauts Basins and Cascades with four cities: Bobo-Dioulasso, Banfora, Orodara and Toussiana. The use of 5M method made it possible to classify the various factors likely to contribute to the depreciation of mango quality. Results. The results showed that the majority of the manufacturing units are artisanal type and do not comply in terms of installation and sanitation. The equipments are rudimentary. The staff have not been trained in good manufacturing and hygiene practices. This derives from the practical solutions for the control, prevention and monitoring of 15 critical control points (CCP) identified during the production of dried mangoes. The CCP control plan including four control points has been established. Indeed, the implementation of the method requires the strict procedure monitoring. Conclusion. This study provided information on the risks associated with the production of dried mangoes in Burkina Faso. It will allow to produce quality dried mangoes and to preserve the health of employees and consumer's by reducing Biological, chemical and physical hazards.

\section{Research Article}

PII: S225199392100012-11

Rec. 30 September 2021

Rev. 18 November 2021

Acc. 21 November 2021

\section{Keywords}

Food safety,

Staff health,

Hazard Analysis and

Critical Control Points,

Dried mango,

Quality,

Burkina Faso

\section{INTRODUCTION}

Food safety is the set of measures adopted in the agriculture, livestock and food production sector to ensure food healthiness from production to consumption. The production of safe food requires the application of good manufacturing practices by the staff through adequate hygiene measures. In addition, it is essential to avoid biological, physical and chemical contaminants that can negatively impact the health of the consumers and employees [1]. During 1990s, the HACCP "Hazard Analysis and Critical Control Points" system was introduced as mandatory measures in certain sectors of the food industry [2]. In recent years, HACCP compliance, often as part of voluntary quality systems (ISO 9000, IFS, BRC, product certifications, etc.), has become a minimum standard for entering the food market [3]. One of the most suitable systems for food industry is the HACCP approach. This recognized, effective and preventive HACCP approach guarantees the hygiene of foodstuffs, worldwide. Currently, this system is widely adopted and implemented by many countries such as United States, Canada, Japan, United Kingdom and European Union member states, some emerging countries and developing countries. Also, as well as international organizations such as World Health Organization (WHO), Food and Agriculture Organization (FAO), especially the Codex Alimentarius Commission are adopted this system [4]. The food problem remains a major concern in developing countries in particular the sub-Saharan Africa countries. In its regions of Africa, studies estimate $40 \%$ of post-harvest losses [5]. This situation represents a major obstacle to the development of food policies to guarantee food security in these different countries. Improving 
this situation requires the development and dissemination of modern agro-processing technologies adapted to local socio-economic contexts specific to each of these countries and compliance with international standards [6]. Burkina Faso is a West African country and particularly concerned by this food safety issue. Indeed, mango is one of the main agricultural crops with an area of 19,737.22 hectares for 9.5 t / ha. Burkina Faso is among the world's leading producers of fresh mango [7] with an estimated annual production of 160,000 tonnes in 2014 and 300,000 tonnes in 2019 [8]. The fresh mango production for 2019 (300,000 tonnes) is up more than $20 \%$ compared to 2018 (197,372 tonnes) [8]. They are four main production regions (Hauts-Bassins, Cascades, Boucle $\mathrm{du}$ Mouhoun and Centre) which produced 243,000 tonnes [9]. Several units are involved in the production of dried mangoes in Burkina Faso. These dried mangoes are consumed locally and imported to certain foreign countries. However, maintaining the quality of mangoes remains a problem [10]). Indeed, physical, biological and chemical contaminants of various origins can be found in food. These risks decrease the quality and can compromise employees and consumer's health. Thus, faced the international trade globalization, to be credible and competitive, the dried mangoes production requires a control aimed at guaranteeing their quality. The major concern of drying units, which want to remain competitive and export their products, is not only to produce products in large quantities but also to take into account the food safety aspect. The implementation of HACCP system in the drying units can effectively guarantee the quality of dried mangoes, expand the market and improve the income of producers [11].

To guarantee the safety of production, the HACCP system can be applied throughout the manufacturing process because the food safety is valuable for the consumer health. A quality process has been undertaken to ensure product safety in the drying units in Burkina Faso. The HACCP system requires many steps such as the identification of the biological, chemical and physical hazards that may exist at each step of drying [12]. The various critical points are identified according to defined critical limits and the development of a plan of control and control of hazards during the production of dried mangoes [13, 14]. The aim of this study was to develop a control plan through the Biological, chemical and physical hazards control plans to ensure employees health during dried mango production.

\section{MATERIALS AND METHODS}

\section{Data processing}

In each city, the survey sheets were administered either individually or to groups of people. The survey sheets were completed by the investigators at different places in the dried mango production chain (reception, drying, and packaging). Three modes of data collection were used: "focus group" group survey during which the forms are filled in during discussions; individual survey during which the interviewer asks the questions to one person and the semi-structured interviews by group were carried out according to the method described by Wentholt et al. [15] which consists of interviewing women and men, separately. The production steps of dried mangoes were monitored and evaluated. The steps followed are reception, ripening, washing, peeling, cutting, scraping, slicing, soaking, mixing, placing in trays, drying, unloading of dry parts, packaging, storage and transport. The information gathered from the dried mango producers was converted into a diagram using the word software.

\section{Hazard analysis method}

To analyze the hazards, the 5M method (Labor, Raw Materials, Materials, Environment and Methods) or cause and effect diagram, also called ISHIKAWA diagram is used. Usually, the causes of all listed hazards must first be investigated using techniques such as FMEA (Failure Modes, Effects and Criticality Analysis) [16, 17]. This procedure makes it possible to determine the types of possible hazards, the sources of each listed hazards and to investigate their effects and their criticality [18].

A hazard was defined as minor if the criticality index $C$ is less than or equal to 15 , major if the criticality index $C$ is more than 15. This threshold was set arbitrarily at the study start after discussions with the parties takeholders (including company staff) and based on previous experiences. It should make it possible to take into account the maximum of sensitive steps. Hazards can arise at each step of production [19], so great rigor and a methodical approach are required for their control. The method of assessing hazards based on their likelihood and severity is shown in Table 1. 
Table 1. Method of assessing hazards according to their likelihood and severity

\begin{tabular}{lcl}
\hline Criteria & Level & Meaning \\
Frequency (F) & 1 & Rarely \\
& 3 & Sometimes \\
& 5 & Often \\
\hline \multirow{2}{*}{ Detectability (D) } & 1 & hazard very easy to detect \\
& 3 & harzard easy to detect \\
\hline \multirow{2}{*}{ Gravity (G) } & 5 & harzard difficult to detect \\
& 1 & Low consequence \\
& 3 & Moderate consequence that may leave non-serious sequelae \\
\hline
\end{tabular}

On the basis of the assigned value, the criticality (C) of each hazard is calculated according to the formula: $C=F^{*} G^{*} D$.

\section{Critical control points (CCP) determination}

This involves determining the steps where the identified hazards must be controlled. The determination of a CCP in the HACCP system is mainly facilitated by the application of the decision tree (Figure l) specific to this approach $[20,21]$. The decision tree allows for a logical reasoning approach. To control the identified hazards, a set of requirements and documents to justify the implementation of good hygiene and laboratory practices have been established $[13,22]$. The hazard analysis and the determination of critical control points (CCP) were carried out according to the recommendations of the Codex Alimentarius, the quality standards [20, 23]. Thus techniques such as brainstorming, inquiry through questions administered to employees, quality managers and production managers, and guided tours from the reception of fresh mangoes to the finished product have made it possible to identify the various dangers. The decision tree which consists of a series of four questions was used. Figure 1 show the decision tree used to control CCP.

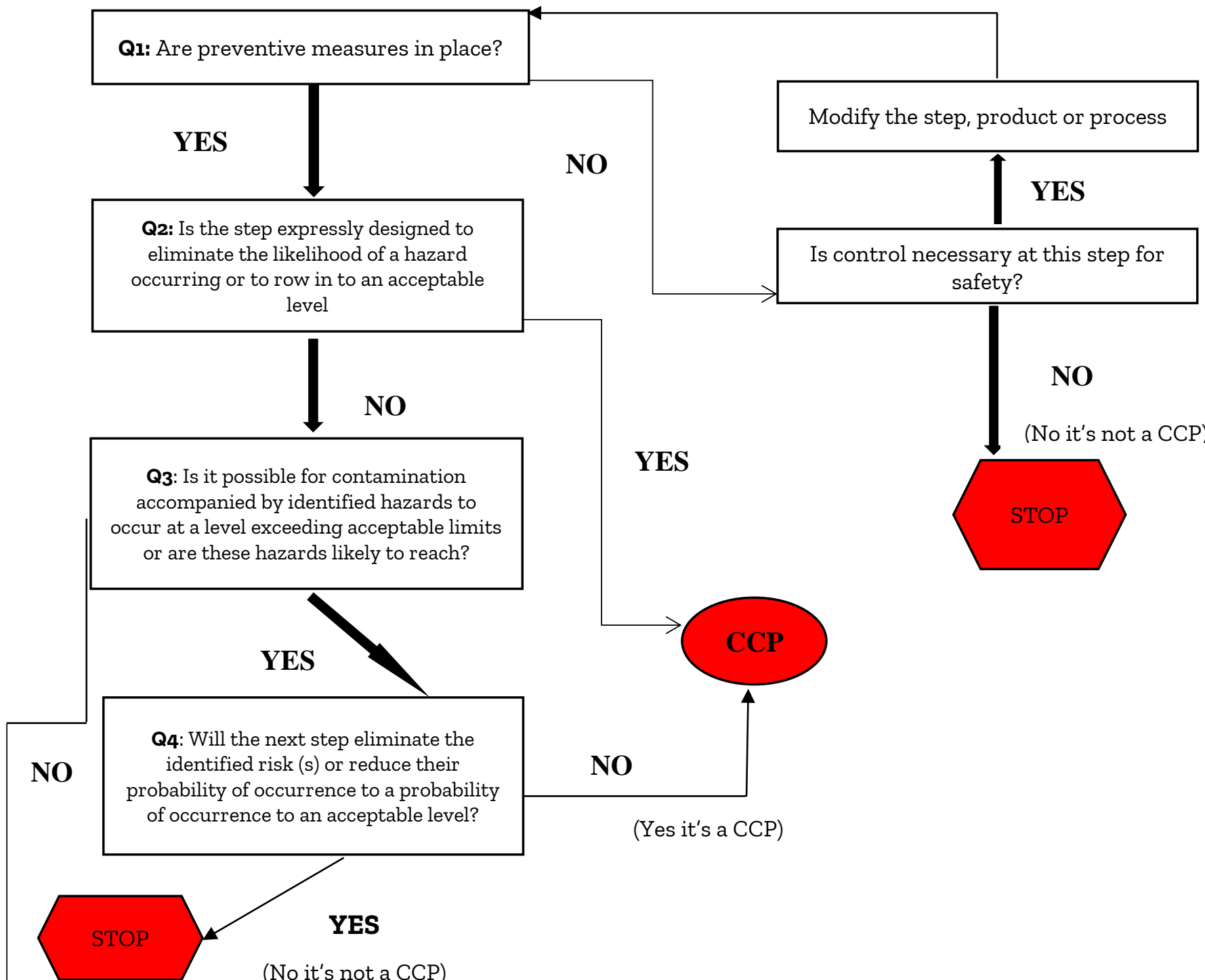

Figure 1. Adapted decision tree 


\section{Assessment of physical, chemical and biological contaminants}

The physical, chemical and biological contaminations of the various steps were evaluated. For physical contamination, they are pieces of wood, iron, boxes, nails, grains of sand and hair. The different chemical contaminants are in particular detergent residues, pesticide residues and heavy metals. Microorganisms from personnel, working area, crates and the presence of mold are biological hazards. Our results are similar to those of FAO [24] who reported that structures inside food production facilities should be solidly constructed of durable materials and be easy to maintain, clean and disinfect. Bimben et al. [25] noted the same for manufacturing facilities for products sensitive to microbial growth, given the role of air as a vector of particulate and microbial contamination. In addition, the temperature should be maintained between 6 and $12^{\circ} \mathrm{C}$ and the hygrometry at a level compatible with the activity. The areas of unpleasant odor, smoke, dust and contaminants are prohibited for food establishments [26]. Quittet and Nelis [26] suggest avoiding water stagnation, soil wetting, for technological reasons. Hazard analysis is a key step in establishing self-control for each of the identified hazards [27]. It makes it possible to judge the risks that could have negative consequences for the consumer and the producer. The assessment of a potential hazard includes, in addition to the possible consequences, the determination of its severity and frequency $[18,28]$. The physical, chemical and biological contaminations of the various steps were evaluated.

\section{Production technology steps of dried mangoes}

\section{Receiving and storage}

Receiving the mango includes quality checking and weighing. The quality of the raw material has an important role in the quality of the dried mango. Thus, it is only possible to produce good products from quality fresh mangoes. The place of storage must be sufficiently clear and free from any source of contamination. It should be carefully chosen (ventilated, dry, well ventilated). It is desirable that mangoes are stored in crates after rigorous sorting. The use of crates is therefore recommended to guarantee the quality of the raw material.

\section{Ripening}

The ripening of mangoes consists in bringing the mangoes to the desired degree of ripening for the rest of the treatments. The technique to be used depends on the variety of mango. For the "Amélie" variety, simple storage in crates in the ripening room is sufficient, because it ripens quickly in a natural way with the risk of too advanced ripening in the event of lack of ventilation or overload in containers. For the "Brook" variety, it will be a question of "forcing" the ripening by covering the mango crates with plastic film.

\section{Sorting and weighing}

Sorting allows you to select the mangoes that have reached the right degree of ripening. During this operation, it is thus a question of constituting homogeneous batches of mangoes having the same degree of maturity and removing suspect fruits (fruits with spots). Stains on the fruit are often due to the action of microorganisms and it is better to eliminate the offending. It is also necessary to discard overripe mangoes so as not to compromise the homogeneity of the product after drying. The management of sorting operations is fundamental for the profitability of drying operations and makes it possible to guarantee the availability of the quantities of raw materials necessary for the daily processing operations and significant reduction in the losses of raw materials due to too advanced ripening.

\section{Washing}

The surface of mangoes naturally carries a lot of impurities, hand dirt and microbial contaminations. The renewal of the water must be regular. The ideal is to carry out the washing in four steps:
A) soaking;
B) first washing of mangoes in plain water to remove organic impurities;
C) rinsing mangoes in bleach to inactivate microorganisms;
D) rinsing the mangoes in potable water to remove the remainder of the bleach. 
A good wash eliminates these different risk factors. The quality and quantity of water used is very important for the success of the operation. The renewal of the water must be regular. The ideal is to carry out the washing in four steps. They are the soaking, the first washing of mangoes in plain water to remove organic impurities, the rinsing mangoes in bleach to inactivate microorganisms and the rinsing of mangoes with potable water to remove the remainder of the bleach.

\section{Peeling and slicing}

Peeling removes the skin from the fruit and is most often done manually using a knife or peeler. Some operators are more skilled with the knife than the peeler. However, the peeler is recommended for the proper conduct of this operation. During this step, it is a question of pitting the flesh of the mango and of cutting. The cutting is carried out with stainless steel knives. This involves cutting the flesh of the mango along three axes (and not two) around the kernel, thus reducing the quantity of pieces of pulp that do not comply with the standard.

\section{Racking and drying}

After placing the mango slices in a rack, the racks are placed in the dryer. The drying process can take anywhere from 18 to 24 hours depending on the technology used, the drying period, the variety of mango and the operator's skill. Putting cut mangoes on racks is important because it has an impact on the quality of the product, the quantity of mango that will be dried in one cycle and the uniformity of drying. The drying consists in eliminating by gradual and partial evaporation of the water of constitution of the fruits by the combined action of air and heat while keeping its organoleptic qualities and microbiological stability: a transfer of heat and a transfer of water are observed. The amount of dried mango produced in one cycle depends on the load introduced into the dryer. It is therefore necessary to load the racks to the maximum that is to say to leave only very small spaces between the parts.

\section{Cooling, unloading and sorting}

The dried mango slices are taken out of the dryer and cooling is carried out followed by homogenization of the water content of the slices (maturation takes place in barrels for 24 hours). After decaying, the dried mangoes are sorted on a stainless steel table (recommended) and classified into two categories: the first and the second choice according to the preference of customers. The characteristics of the two categories of commonly used dried mangoes are the first choice: orange to yellow color, good texture, accentuated fragrance, size and thickness of the slices to be defined according to the customer, and the second choice: too small but same taste quality with the first choice.

\section{Conditioning}

The function of the packaging is to protect the finished product against external attacks (pests, physical and chemical factors). The conditioning is done in two phases. The phases are the primary packaging (bagging) and the secondary packaging (cardboard packing). The primary packaging is carried out immediately after sorting to better preserve the finished product. This packaging is done with two-layer sachets (polyethylene / polyamide) which prevent the passage of humidity and air. Labeling should be considered at the bag level and after packaging in cardboard for reasons of traceability. It allows you to find all the information relating to a finished product (raw materials, processing conditions, storage and transport conditions...).

\section{Storage}

The finished products (bagged and cardboard) are stored in a warehouse on pallets provided for this purpose for shipping. The storage conditions in the store are a temperature less than or equal to $25^{\circ} \mathrm{C}$, low light and low humidity. The room must be ventilated without allowing dust to penetrate. The boxes are stacked according to a "cross" procedure. The production diagram shows a semi-industrial manufacturing process of dried mangoes for export. Figure 2 shows the variants of the process with the technological alternatives. The different dangers are listed in table 2. 


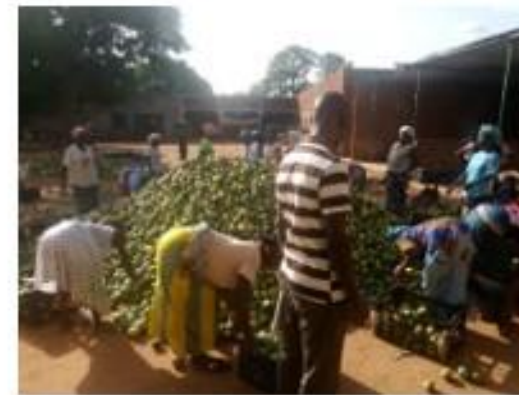

2. Reception of fresh mango

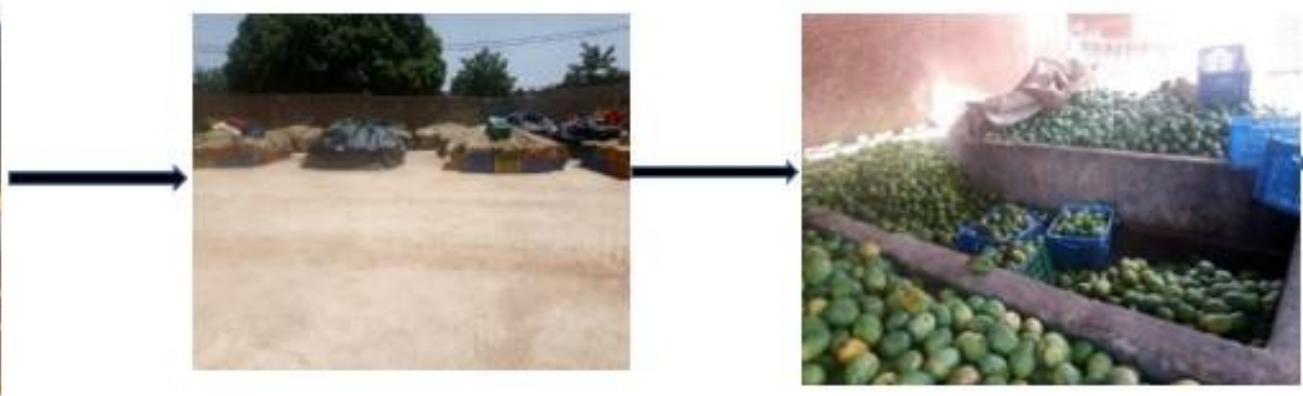

2. Storage and ripening of mango
3. Sorting and weighing mangoes ready for processing

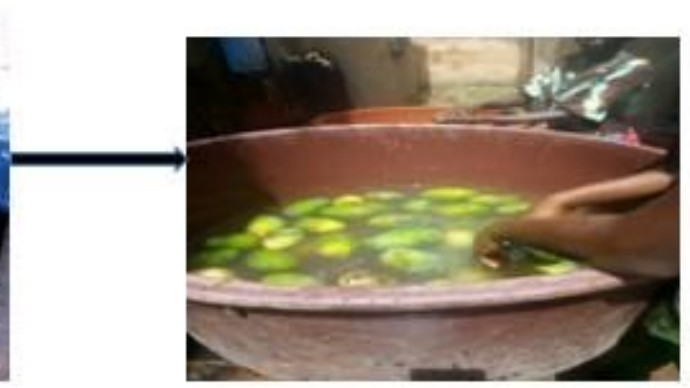

4. Washing mangoes

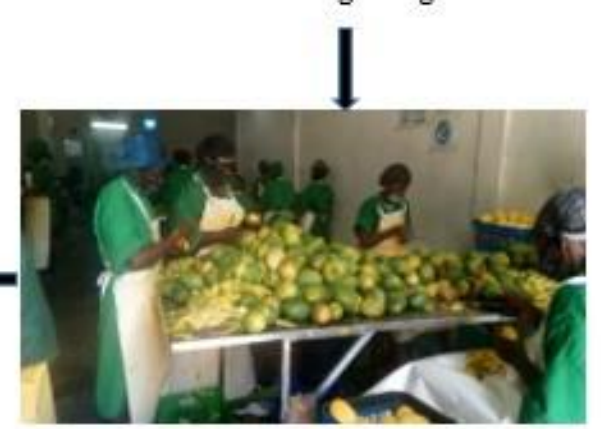

5. Peeling and weighing

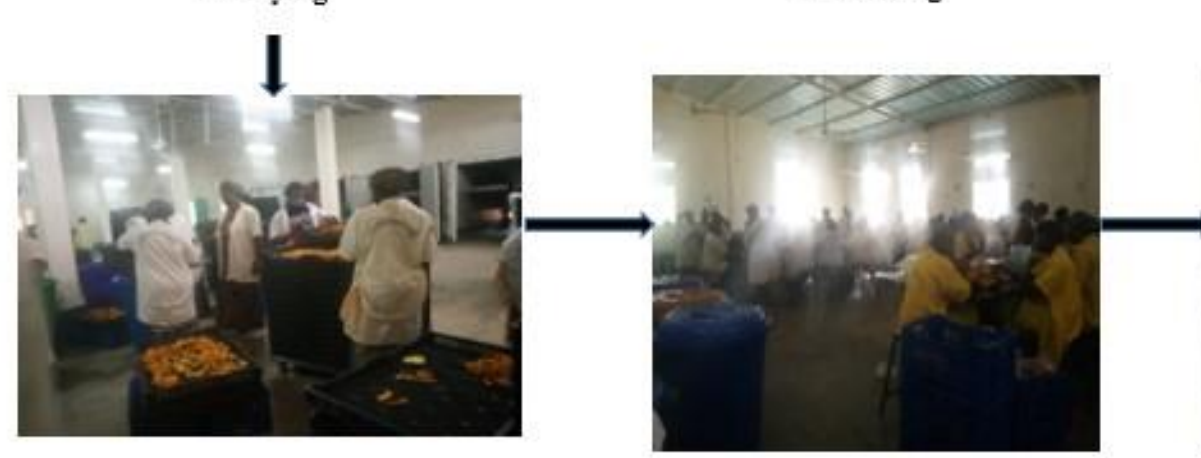

9. Cooling and unloading of dry parts
10. Sorting, classification and weighing

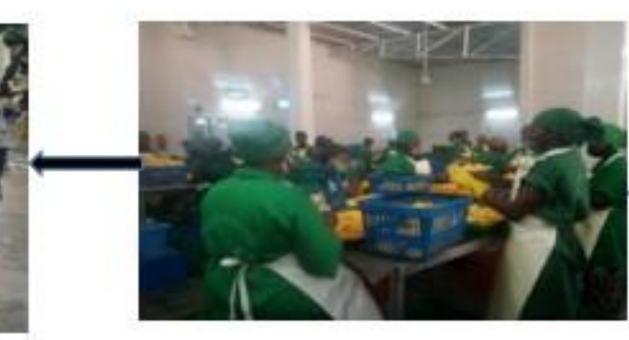

6. Slicing/slicing and weighing

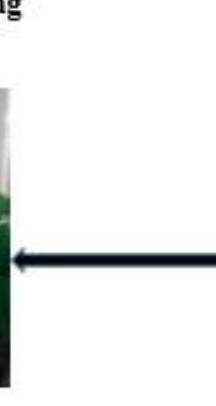

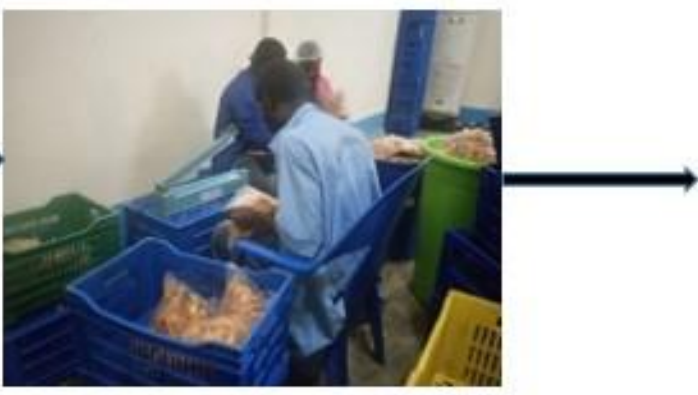

11. Conditioning

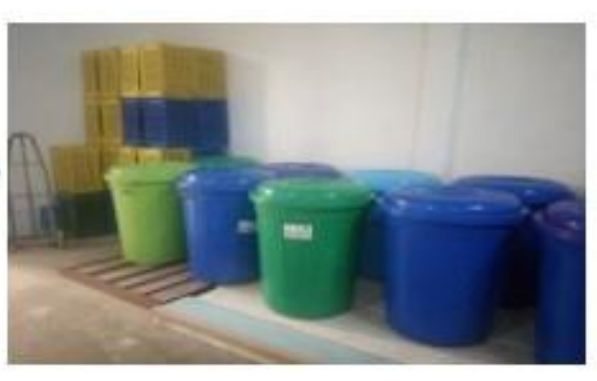

12. Storage

Figure 2. Steps followed during the production of dried mangoes 
Table 2. Hazard identification

\begin{tabular}{|c|c|c|c|c|c|c|}
\hline \multicolumn{7}{|c|}{ Identification of risks } \\
\hline Step & $\begin{array}{l}\text { Nature of } \\
\text { danger }\end{array}$ & Method & Equipment & Middle & Workforce & Raw material \\
\hline \multirow{3}{*}{ Reception } & Chemical & & Detergent residue on the crates & Poor rinsing of storage areas & Cosmetic products & $\begin{array}{l}\text { Chemical (pesticides, } \\
\text { hydrocarbons) and heavy metals }\end{array}$ \\
\hline & Organic & & $\begin{array}{l}\text { Microorganisms in mangoes from } \\
\text { the crates }\end{array}$ & $\begin{array}{l}\text { Microorganisms from poorly } \\
\text { maintained reception area }\end{array}$ & $\begin{array}{l}\text { Microorganisms from falling } \\
\text { crates } \\
\text { and staff }\end{array}$ & $\begin{array}{l}\text { Fly Larva and Microorganisms } \\
\text { (Animal and human defect) }\end{array}$ \\
\hline & Physical & Pebbles in the mango & Pieces of crate in mango & & Nails & $\begin{array}{l}\text { Pieces of wood and iron in the } \\
\text { mango }\end{array}$ \\
\hline \multirow{3}{*}{ Ripening } & Chemical & & $\begin{array}{l}\text { Tarpaulin contaminants (residues, } \\
\text { detergent, Tarpaulin components) }\end{array}$ & Poor rinsing of storage areas & & \\
\hline & Organic & $\begin{array}{l}\text { Microorganisms } \\
\text { resulting from } \\
\text { improper handling and } \\
\text { / or rotting of bottom } \\
\text { mangoes }\end{array}$ & $\begin{array}{l}\text { Microorganisms resulting from } \\
\text { poor tarpaulin maintenance }\end{array}$ & $\begin{array}{l}\text { Microorganisms from poorly } \\
\text { maintained ripening area, } \\
\text { infestation (mice, margouillats) } \\
\text { And by the cash registers }\end{array}$ & & $\begin{array}{l}\text { Microorganisms and mold due to } \\
\text { poor hygiene }\end{array}$ \\
\hline & Physical & & $\begin{array}{l}\text { Piece of crate in mango due to poor } \\
\text { quality of crate }\end{array}$ & $\begin{array}{l}\text { Piece of glass, seed of sand, } \\
\text { broken bulb }\end{array}$ & & \\
\hline \multirow{3}{*}{ Washing } & Chemical & & & $\begin{array}{l}\text { Detergent residue due to } \\
\text { improper washing of the tubs }\end{array}$ & Staff cosmetics & \\
\hline & Organic & $\begin{array}{l}\text { Microorganisms } \\
\text { resulting from the } \\
\text { wrong frequency of } \\
\text { changing the wash } \\
\text { water }\end{array}$ & $\begin{array}{l}\text { Microorganisms due to improper } \\
\text { washing of tubs, tea towels and } \\
\text { others }\end{array}$ & $\begin{array}{l}\text { Microorganisms due to the } \\
\text { cleanliness of the premises }\end{array}$ & $\begin{array}{l}\text { Microorganisms resulting } \\
\text { from bad staff behavior }\end{array}$ & $\begin{array}{l}\text { Microorganisms resulting from } \\
\text { poor handling mangoes }\end{array}$ \\
\hline & Physical & Pieces of crates & Broken glass and piece of crates & Glass breakage & Nails, hair & \\
\hline \multirow{3}{*}{ Peeling } & Chemical & & Poor rinsing of equipment & $\begin{array}{l}\text { Detergent residue due to poor } \\
\text { maintenance of the area }\end{array}$ & Cosmetic product residues & \\
\hline & Organic & & Poor rinsing of equipment & $\begin{array}{l}\text { Bacteria due to poor room } \\
\text { maintenance }\end{array}$ & $\begin{array}{l}\text { Microorganisms resulting } \\
\text { from poor personal hygiene, } \\
\text { clothing and staff behavior } \\
\text { (hands, saliva, sweat) }\end{array}$ & $\begin{array}{l}\text { Microorganisms from fallen } \\
\text { mangoes }\end{array}$ \\
\hline & Physical & & $\begin{array}{l}\text { Piece of iron in mango due to wear } \\
\text { of blades, peeler }\end{array}$ & Lamp breakage & Nails and hair & \\
\hline \multirow{3}{*}{ Cutout } & Physical & $\begin{array}{l}\text { Pieces of pits on the } \\
\text { slices (Manual cutting) }\end{array}$ & $\begin{array}{l}\text { Pieces of iron due to material wear } \\
\text { on the products }\end{array}$ & $\begin{array}{l}\text { Pieces of glass due Unprotected } \\
\text { lamp breakage. }\end{array}$ & Hair, nails and personal items & $\begin{array}{l}\text { Remains of skin due to poor } \\
\text { peeling and pieces of pits due to } \\
\text { poor cutting. }\end{array}$ \\
\hline & Chemical & & $\begin{array}{l}\text { Detergent and disinfectant } \\
\text { residues }\end{array}$ & $\begin{array}{l}\text { Detergent and disinfectant } \\
\text { residues }\end{array}$ & Cosmetic product residues: & High MRL level in mangoes \\
\hline & Organic & & $\begin{array}{l}\text { Pathogens due to inefficient } \\
\text { washing }\end{array}$ & $\begin{array}{l}\text { Bacteria and mold caused by } \\
\text { poor maintenance }\end{array}$ & $\begin{array}{l}\text { Microorganisms from the } \\
\text { discharge of the eyes, nose, }\end{array}$ & Parasites and germs due to rot. \\
\hline
\end{tabular}

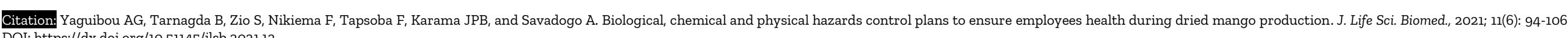
DOI: https://dx.doi.org/10.51145/jlsb.2021.12 


\begin{tabular}{|c|c|c|c|c|c|c|}
\hline & & & & & $\begin{array}{l}\text { ears (eg Staphylococcus } \\
\text { panaris or boils) }\end{array}$ & \\
\hline \multirow{3}{*}{ Scraping } & Physical & $\begin{array}{l}\text { Piece of kernels in the } \\
\text { pulp }\end{array}$ & $\begin{array}{l}\text { Pieces of iron due to material wear } \\
\text { (ex knife) on the products }\end{array}$ & Paint debris from the walls. & Hair, nails and personal items & $\begin{array}{l}\text { Remains of skins due to poor } \\
\text { peeling, and pieces of pits due to } \\
\text { poor cutting. }\end{array}$ \\
\hline & Chemical & & $\begin{array}{l}\text { Detergent and disinfectant } \\
\text { residues }\end{array}$ & $\begin{array}{l}\text { Detergent and disinfectant } \\
\text { residues }\end{array}$ & Cosmetic product residues & \\
\hline & Organic & & $\begin{array}{l}\text { Pathogens due to inefficient } \\
\text { washing }\end{array}$ & $\begin{array}{l}\text { Bacteria and mold due to poor } \\
\text { maintenance }\end{array}$ & $\begin{array}{l}\text { Germs from discharge from } \\
\text { eyes, nose and ears }\end{array}$ & Parasites and germs due to rot. \\
\hline \multirow{3}{*}{ Slicing } & Physical & $\begin{array}{l}\text { Pieces of pits on the } \\
\text { slices }\end{array}$ & $\begin{array}{l}\text { Pieces of iron due to material wear } \\
\text { (eg. knife) }\end{array}$ & Paint debris from the walls. & Hair, nails, personal item. & $\begin{array}{l}\text { Remains of skin due to improper } \\
\text { peeling and Pieces of pits }\end{array}$ \\
\hline & Chemical & - & Detergent and disinfectant residue. & $\begin{array}{l}\text { Detergent and disinfectant } \\
\text { residues }\end{array}$ & Cosmetic product residues: & - \\
\hline & Organic & - & $\begin{array}{l}\text { Pathogenic germs due to inefficient } \\
\text { washing. }\end{array}$ & $\begin{array}{l}\text { Bacteria and mold caused by } \\
\text { poor maintenance }\end{array}$ & $\begin{array}{l}\text { Germs from the discharge of } \\
\text { the eyes, nose, ears (eg } \\
\text { Staphylococcus due to a } \\
\text { whitlow or boil) }\end{array}$ & $\begin{array}{l}\text { Remains of skins due to poor } \\
\text { peeling and Pieces of pits due to } \\
\text { poor cutting. }\end{array}$ \\
\hline \multirow{3}{*}{ Soaking } & Physical & & $\begin{array}{l}\text { Pieces of plastic basket (broken } \\
\text { case) }\end{array}$ & Flies and Flying Insects. & Hair and staff items & $\begin{array}{l}\text { Remains of skins due to poor } \\
\text { peeling and Pieces of pits due to } \\
\text { poor cutting. }\end{array}$ \\
\hline & Chemical & High sulfur content & $\begin{array}{l}\text { Detergent residues from improper } \\
\text { washing of baskets and bins }\end{array}$ & $\begin{array}{l}\text { Detergent and disinfectant } \\
\text { residues }\end{array}$ & $\begin{array}{l}\text { Residues from cosmetic } \\
\text { products: improperly washed } \\
\text { hands }\end{array}$ & 1 \\
\hline & Organic & $\begin{array}{l}\text { Microorganisms in the } \\
\text { steep water }\end{array}$ & $\begin{array}{l}\text { Pathogens resulting from } \\
\text { inefficient washing }\end{array}$ & Airborne microorganisms & $\begin{array}{l}\text { Germs from discharge from } \\
\text { eyes, nose and ears }\end{array}$ & $\begin{array}{l}\text { Parasites and germs caused by } \\
\text { rot }\end{array}$ \\
\hline \multirow{3}{*}{ Mixing of purees } & Physical & & Pieces of broken blades & $\begin{array}{l}\text { Debris of glass, insects in the } \\
\text { middle }\end{array}$ & $\begin{array}{l}\text { Bad handling during cutting } \\
\text { and presence of varnish on } \\
\text { nails, hair }\end{array}$ & $\begin{array}{l}\text { Pieces of hair or wood, cores, } \\
\text { fibers and dust }\end{array}$ \\
\hline & Chemical & & $\begin{array}{l}\text { Sulfur overdose / under dose due to } \\
\text { improper calibration and residues } \\
\text { of cleaning or disinfection products }\end{array}$ & Paint residue (mural) & $\begin{array}{l}\text { Cosmetics and sulfur dosage } \\
\text { error. }\end{array}$ & $\begin{array}{l}\text { Pesticide residues or heavy } \\
\text { metals }\end{array}$ \\
\hline & Organic & & $\begin{array}{l}\text { Microorganisms resulting from } \\
\text { poor equipment maintenance (open } \\
\text { mixer) }\end{array}$ & Germs due to poor maintenance & $\begin{array}{l}\text { Microorganisms from staff } \\
\text { (colds, coughs, diarrhea, } \\
\text { sweat, saliva, dirty nails after } \\
\text { leaving the toilet) }\end{array}$ & $\begin{array}{l}\text { Larvae and other } \\
\text { microorganisms on undetected } \\
\text { rotten mangoes }\end{array}$ \\
\hline \multirow{3}{*}{ Racking } & Physical & & $\begin{array}{l}\text { Debris from trays and cups, debris } \\
\text { from brush, rack and net }\end{array}$ & $\begin{array}{l}\text { Grains of sand, small pebbles } \\
\text { from dust. Insects, broken lamp, } \\
\text { poorly cleaned dust on the fans }\end{array}$ & $\begin{array}{l}\text { Broken nail, pimples, shiny } \\
\text { Polish on nails, hair }\end{array}$ & $\begin{array}{l}\text { Pieces or wood, cores and fibers } \\
\text { Dust contained in sulfur } \\
\text { following poor storage }\end{array}$ \\
\hline & Chemical & & $\begin{array}{l}\text { Sulfur overdose / underdose due to } \\
\text { improper calibration } \\
\text { Presence of residue from cleaning } \\
\text { or disinfection products }\end{array}$ & $\begin{array}{l}\text { Residue of cleaning or } \\
\text { disinfection products (floors, } \\
\text { walls and worktop) }\end{array}$ & $\begin{array}{l}\text { Cosmetic product residues, } \\
\text { sulfur dosage error. }\end{array}$ & $\begin{array}{l}\text { Pesticide residues or presence of } \\
\text { heavy metals }\end{array}$ \\
\hline & Organic & & & $\begin{array}{l}\text { Poor maintenance of equipment } \\
\text { (reuse of trays) quality of } \\
\text { washing water, racks, nets, }\end{array}$ & $\begin{array}{l}\text { Poor maintenance of the } \\
\text { room. }\end{array}$ & $\begin{array}{l}\text { Microorganisms (health, personal } \\
\text { hygiene and staff behavior) }\end{array}$ \\
\hline
\end{tabular}

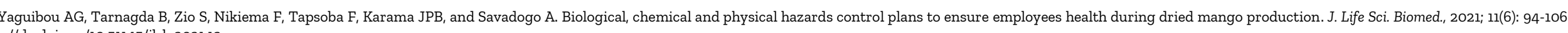
DOI: https://dx.doi.org/10.51145/jlsb.2021.12 


\begin{tabular}{|c|c|c|c|c|c|c|}
\hline & & & & basket & & \\
\hline \multirow{3}{*}{ Drying } & Physical & & $\begin{array}{l}\text { Rivets, points due to poor } \\
\text { maintenance of the dryers }\end{array}$ & & $\begin{array}{l}\text { Contaminants from } \\
\text { personnel (nails, pimples, } \\
\text { hair, rings) }\end{array}$ & $\begin{array}{l}\text { Pieces of wood, pits and fiber } \\
\text { contained in the mango. }\end{array}$ \\
\hline & Chemical & & $\begin{array}{l}\text { Residues of cleaning or disinfection } \\
\text { products, Interior painting of } \\
\text { tunnels }\end{array}$ & & $\begin{array}{l}\text { Cosmetic product residues } \\
\text { during permutations }\end{array}$ & $\begin{array}{l}\text { Pesticide residues or presence of } \\
\text { heavy metals }\end{array}$ \\
\hline & Organic & $\begin{array}{l}\text { Microorganisms (mold, } \\
\text { yeast due to incorrect } \\
\text { temperature control) }\end{array}$ & $\begin{array}{l}\text { Germs on the racks and poorly } \\
\text { maintained tunnel }\end{array}$ & & $\begin{array}{l}\text { Microorganisms from staff } \\
\text { behavior }\end{array}$ & \\
\hline \multirow{3}{*}{ Unlaying } & Physical & & $\begin{array}{l}\text { Crates, nets, trays, plastics, worn } \\
\text { iron }\end{array}$ & Broken glasses, insects. & Nails and hair. & $\begin{array}{l}\text { Pieces of hurdles and worms, hair } \\
\text { or wood, stones and fibers }\end{array}$ \\
\hline & Chemical & & $\begin{array}{l}\text { Residues of cleaning or disinfection } \\
\text { products on equipment }\end{array}$ & $\begin{array}{l}\text { Residues of cleaning or } \\
\text { disinfection products in the } \\
\text { room }\end{array}$ & Cosmetic product residues & $\begin{array}{l}\text { Pesticide residues or presence of } \\
\text { heavy metals, sulphite }\end{array}$ \\
\hline & Organic & & $\begin{array}{l}\text { Microorganisms due to poor } \\
\text { equipment maintenance }\end{array}$ & $\begin{array}{l}\text { Microorganisms on walls and } \\
\text { floors } \\
\text { Contamination due to poor } \\
\text { maintenance of the premises }\end{array}$ & $\begin{array}{l}\text { Contaminants from } \\
\text { personnel }\end{array}$ & $\begin{array}{l}\text { Larvae and other } \\
\text { microorganisms }\end{array}$ \\
\hline \multirow{3}{*}{ Conditioning } & Physical & & Bits, scissor nut, pieces of plastic, & $\begin{array}{l}\text { Glass breakage, insects, wood } \\
\text { dust, dust }\end{array}$ & $\begin{array}{l}\text { Nails, hair, wood, thread, } \\
\text { paint, dried, fly, sandworm, } \\
\text { skin, blood }\end{array}$ & $\begin{array}{l}\text { Pieces of hair or wood, cores and } \\
\text { fibers }\end{array}$ \\
\hline & Chemical & & $\begin{array}{l}\text { Cleaning or disinfection } \\
\text { Chemical residue on cartons or } \\
\text { bags }\end{array}$ & $\begin{array}{l}\text { Residues of cleaning or } \\
\text { disinfection products }\end{array}$ & Cosmetic product residues & $\begin{array}{l}\text { Pesticide residues or presence of } \\
\text { heavy metals, sulphite }\end{array}$ \\
\hline & Organic & & $\begin{array}{l}\text { Microorganisms from dirty scissor } \\
\text { handles, packaging, weighing } \\
\text { tables, drums, plate welders, poorly } \\
\text { maintained tea towels. }\end{array}$ & $\begin{array}{l}\text { Microorganisms resulting from } \\
\text { poor maintenance of premises }\end{array}$ & $\begin{array}{l}\text { Microorganisms from } \\
\text { personnel (hygiene behavior, } \\
\text { health) }\end{array}$ & $\begin{array}{l}\text { Microorganisms from larvae and } \\
\text { other microorganisms }\end{array}$ \\
\hline \multirow{3}{*}{ Storage } & Physical & & $\begin{array}{l}\text { Pieces of pen, scissor tips in boxes } \\
\text { or bags }\end{array}$ & & $\begin{array}{l}\text { Foreign bodies carried by } \\
\text { pests }\end{array}$ & $\begin{array}{l}\text { Pieces of pen, scissor tips in } \\
\text { boxes or bags }\end{array}$ \\
\hline & Chemical & & Yeast mold bacteria on pallets & $\begin{array}{l}\text { Molds, yeast and pest infestation } \\
\text { (rodent margouillats) }\end{array}$ & & \\
\hline & Organic & & & Molds and yeasts on the pallets & $\begin{array}{l}\text { Molds and yeasts, Pest } \\
\text { infestation (margouillat } \\
\text { rodent) }\end{array}$ & \\
\hline \multirow{3}{*}{ Transport } & Physical & Physical & & & & \\
\hline & Chemical & Chemical & & $\begin{array}{l}\text { Pesticides, and hydrocarbons in } \\
\text { the transport vehicle }\end{array}$ & & \\
\hline & Organic & & & $\begin{array}{l}\text { Molds and yeasts due to poor } \\
\text { maintenance of the truck. }\end{array}$ & & \\
\hline
\end{tabular}

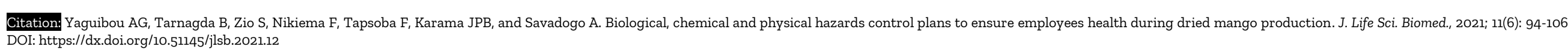


Table 3. Hazard analysis and critical point determination

\begin{tabular}{|c|c|c|c|c|c|c|c|}
\hline \multicolumn{7}{|c|}{ Hazard analysis } & \multirow[b]{2}{*}{ CCP } \\
\hline Step & Nature of danger & Source of danger & precautionary measure & Frequency & Gravity & Score & \\
\hline \multirow{5}{*}{ Unlaying } & $\begin{array}{l}\text { Chemical contamination by residues of cleaning } \\
\text { or disinfection products }\end{array}$ & $\begin{array}{l}\text { Poor rinsing of cleaned or } \\
\text { disinfected equipment }\end{array}$ & Train on BPH & 2 & 1 & 2 & NO \\
\hline & & & Check the equipment before use & & & & \\
\hline & \begin{tabular}{|l|} 
Chemical contamination by cosmetic product \\
residues
\end{tabular} & Poor staff hand washing & & & & & NO \\
\hline & & & Sensitize staff on GHP & 2 & 2 & 4 & \\
\hline & & & $\begin{array}{l}\text { Regularly check these small items } \\
\text { before use }\end{array}$ & 2 & 2 & 4 & \\
\hline \multirow{6}{*}{ Conditioning } & $\begin{array}{l}\text { Physical contamination by debris from racks, nets, } \\
\text { trays, plastics, iron. }\end{array}$ & $\begin{array}{l}\text { Wear or breakage of trays, nets, } \\
\text { trays }\end{array}$ & & & & & NO \\
\hline & Physical contamination by broken glass, insects. & $\begin{array}{l}\text { Broken lamps without hood } \\
\text { protection }\end{array}$ & & & & & \\
\hline & & Lack of insect sensors & & 1 & 1 & NO & 1 \\
\hline & Physical contamination by nails, hair. & Bad behavior & & & & & \\
\hline & & Clothing & & 2 & 4 & NO & 2 \\
\hline & $\begin{array}{l}\text { Chemical contamination by cosmetic product } \\
\text { residues }\end{array}$ & Poor hand washing & & & & & \\
\hline \multirow{5}{*}{ Conditioning } & $\begin{array}{l}\text { Physical contamination by bits, scissor nuts, } \\
\text { pieces of plastic, }\end{array}$ & & $\begin{array}{l}\text { Regularly check tools and regular } \\
\text { monitoring of equipment }\end{array}$ & & & & \\
\hline & Physical contamination by broken glass, insects. & & & & & & \\
\hline & Microbial contamination from personnel & $\begin{array}{l}\text { Wear and lack of maintenance of } \\
\text { tools and work equipment }\end{array}$ & Protect bulbs with covers & & & 4 & \\
\hline & Microbial contamination from scissor handles & Bulbs not protected by covers & & 2 & 2 & & NO \\
\hline & \begin{tabular}{|l|} 
Microbial contamination from packaging, \\
weighing tables, drums. \\
\end{tabular} & Bad behavior hygiene, health & \begin{tabular}{|l|} 
Train staff on good hygiene \\
practices.
\end{tabular} & & & 4 & \\
\hline \multirow{5}{*}{ Storage } & Chemical contamination by mixed storage & & & 2 & 2 & & NO \\
\hline & & Ineffective washing or cleaning & $\begin{array}{l}\text { Regular monitoring of washing or } \\
\text { cleaning of equipment }\end{array}$ & & & & \\
\hline & Physical contamination by pests & & & & & & \\
\hline & & $\begin{array}{l}\text { Irregular or inefficient monitoring of } \\
\text { equipment cleanliness }\end{array}$ & & & & & \\
\hline & $\begin{array}{l}\text { Microbial contamination due to bacteria, mold and } \\
\text { yeast on the pallets }\end{array}$ & & $\begin{array}{l}\text { Raise awareness among staff on the } \\
\text { prohibition of mixed storage }\end{array}$ & & & & \\
\hline
\end{tabular}

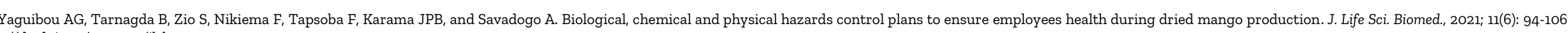
Citation: Yaguibou AG, Tarnagda B, Zio S, N1
DOI: https://dx.doi.org/10.51145/jlsb.2021.12 
These hazards were subsequently classified and assessed using the Cause-Effect Diagram and Hazard Analysis-Critical Point Control method, respectively. Among the fifteen critical control points (CCP), four were identified at the steps of unloading of dry parts, packaging, storage and transport. The control requires training, awareness and control of equipment. Indeed, the capacity building of agents is very important. This ensures that staffs are trained in good manufacturing practices. Also, employees whose work has a greater impact on food safety receive more specialized instruction.

All potential hazards that could threaten the health of the consumer or the merchantability of the finished products, have been identified due to poor quality of the raw material, or failure during manufacture or during storage. This hazard analysis should be reviewed at least once a year or whenever necessary [5]. When the hazards are analyzed, and their levels of occurrence during manufacturing and their cause are identified, each step of the manufacturing flowchart has been evaluated to see if it is a critical point. For each step considered critical, critical limits have been defined. These make it possible to know whether the control measure for the hazard in question has been applied correctly or not. Whenever possible, the critical limits have been chosen so that their violation indicates a slip towards a danger zone, but well before the appearance of the danger.

The main elements of the HACCP analysis are summarized in Tables 2 and 3. The appropriate control and preventive measures have been identified following the identification of the cause of each hazard [29]. This varies according to the level of occurrence of the danger on the production diagram (Figure 2).

The application or the implementation of the developed control plan will make it possible to eliminate or reduce to an acceptable level the dangers which led to the 15 other CCP identified during the study. In short, the 15 critical control points identified from the reception of raw materials to the finished product are located mainly at the level of the steps of reception of raw materials, packaging, water treatment, beverage preparation, bottle rinsing, capping and storage. Moreover, it is following this that the control plan was put in place with its six control points. So, after identification of a non-conformity following an inspection, a corrective action must be implemented as follows: search for the root causes and possible solutions; choice of a solution; implementation of the solution; evaluation of the implementation; refer to the mastery plan. The control of CCP attests that a foodstuff conforms to well-defined specific characteristics. The internationalization of trade and consumer demands are all challenges facing players in the agri-food market. In this context, a growing number of national and international standards (including the regulatory requirements in force in the ECOWAS zone), incorporating the provisions of the best-known ISO standards, are emerging as an international standard in terms of assurance quality as well as in African countries [30]. Most of our national companies encounter great difficulties in setting up a quality management system. These problems are generally accentuated due to the weakness of the means available; difficulty understanding and applying standards; costs associated with setting up and maintaining such a system ; the lack of qualified personnel in the implementation and management of quality management tools and the lack of immediate interest for society in the implementation of such an approach.

Given the need to improve the sanitary and organoleptic quality of dried mangoes and to control production conditions, the manufacturing units should adhere to the process of applying regulations and initiating good hygiene practices and good manufacturing practices. This suppose, on the part of the quality managers, a voluntary approach towards the acquisition of training on food hygiene as well as on a set of quality management tools in general and the mastery of national standards such as baseline if international standards prove to be too demanding at the start of the process. This approach would be a prerequisite for the implementation of the HACCP plan in line with the reality of each environment. According to Torkar and Teger cited by Ndungu et al. [31], to ensure food safety and reduce risks, the HACCP (Hazard Analysis Critical Control point) system or hazard analysis and control of critical points should be implemented and that of quality assurance at the level of the dried mango production units. However, the implementation of the HACCP system, according to the Codex Alimentarius, initially requires the implementation of good practices [32]. Muffok et al. [33] have shown that ISO 22000 is the only international standard that harmonizes food safety management practices according to essential requirements such as prerequisite program and HACCP in order to guarantee food safety. However, Louis Bonne [34], showed the difficulties of setting up a Health control plan based on good hygiene and manufacturing practices and the HACCP method, traceability due to the complexity of documents and methods application. As they develop and aim to increase their production scale, as they deign to invest more, in material, financial and human resources in order to reach the required levels of higher and higher. In the case of this study, the search for quality may require that the units which are foreign to the aforementioned procedures, adapt to the new quality requirements, especially with regard to food hygiene. 
This study aimed to diagnose the hygiene and manufacturing practices of dried mangoes within the manufacturing units in Bobo-Dioulasso, Banfora, Orodara and Toussiana. The results showed that the majority of the manufacturing units are of the artisanal type and do not comply with standards, generally with regard to facilities, layout, sanitation, hygiene and manufacturing practices. The equipment used was rudimentary. Also, this work was an opportunity to propose improvements, in particular on the development and arrangement of flows as well as the means of control. The staffs were poorly educated and routine, and have not been trained in hygiene standards and various procedures. Among the fifteen critical control points (CCP), four were identified at the steps of unloading of dry parts, packaging, storage and transport. Efforts should be made to develop this specialty and produce on a large scale dried mangoes of quality that can meet the requirements of the national and international market. An initiation into the application of good hygiene practices and good manufacturing practices is a preliminary step which would allow the manufacturing units, concerned to improve the quality of dried mangoes, to offer consumers healthy products while facing to the competition. In perspective, future studies we plan to assess the physicochemical, microbiological and chemical contaminants (pesticides and metals) quality of dried food.

\section{DECLARATIONS}

\section{Authors' Contributions}

All authors contributed equally to the conception and design of the study.

\section{Acknowledgements}

All authors contributed equally to the conception and design of the study.

\section{Competing interests}

The authors declare that they no competing interests.

\section{REFERENCES}

1. Roesel K and Grace D. Food safety and informal markets: Animal products in sub-Saharan Africa. 2016; Nairobi, Kenya. DOI: https://doi.org/10.4324/9781315745046

2. Cormier RJ, Mallet M, Chiasson S, Magnússon H and Valdimarsson G. Effectiveness and performance of HACCP-based programs. Food Control. 2007; 18 (6): 665-671. DOI: 10.1016/j.foodcont.2006.02.019

3. Romano D, Cavicchi A, Rocchi B and Stefani G. Costs and benefits of compliance for HACCP regulation in the Italian meat and dairy sectors. Acta Agriculturae Scand, Section C. 2004; 2(1): 52-59 https://ageconsearch.umn.edu/record/24983/files/sp04ro02.pdf

4. Dergal NB. Evaluation of management systems for the safety and quality of aquaculture of Nile tilapia "Oreochromis niloticus" in western Algeria. Doctoral thesis. 2015 ; University of Liège, Belgium, Faculty of Veterinary Medicine Department of Food Sciences, 244 p. https://theses.univ-oranl.dz/document/14201513t.pdf

5. Tounkara LS, Beye C, Cisse N, Laurent L and Diop A. Reduction of post-harvest losses of mango by the production of vinegar. 2011 ; ITA-CWBI-FNRAA, p. 8 http://dspace.univ-eloued.dz/handle/123456789/348

6. Mwamini, B, Zola S, Jean W, Munamire B and Matabaro C. Analysis of hygiene and manufacturing practices and assessment of the quality of Mashanza in 12 production units in South Kivu. Journal of Animal \& Plant Sciences. 2019; 42 (3): 7314-7329. https://doi.org/10.35759/JAnmPlSci.v42-3.4

7. Arnoldus $\mathrm{M}$, Van der Pol F and Ravry C. Juicy business or bitter disappointment: what is the future of mango products in Burkina Faso and Mali? Prospects and strategies for the production and marketing of dried mango, mango pulp and juice. Royal Institute of the Tropics (KIT). 2011; Amsterdam, the Netherlands, p. 143. http://www.bibalex.org/search4dev/files/374777/213310.pdf

8. Economist from Faso. Mango campaign 2019: Production up by 20 \%. Journal Economie du Faso. 2020. Edition No. 326. www.ifc.org $>$ wps > wcm > connect > 201907-CPSD-Burkina-Faso-EN.

9. Arnoldus $\mathrm{M}$ and Van der Pol F. Improving the performance of the processed mango products sector in Burkina Faso and Mali. A study for the World Bank, PCDA and PAFASP, funded by the European Union, 2009; 116 . http://www.slire.net/download/1561/1wstdo5rapport_fili_re_mangue_transform_e_french.pdf

10. Kanté-Traore H, Hagrétou Sawadogo-Lingani H, Issiaka Seogo I, Kabore D and Dicko MH. Mango processing processes and level of knowledge of quality standards by production units in Burkina Faso. International Journal of Biological and Chemical Sciences, 2017 ; 11(1): 195. DOI: 10.4314/ijbcs.v1lil.16

11. Ropkins $\mathrm{K}$ and Beck AJ. Application of hazard analysis critical control points (HACCP) to organic chemical contaminants in food. Critical reviews in food science and nutrition. 2002; 42 (2): 123-149. https://doi.org/10.1080/10408690290825484

12. López PDS, Sandia MG Bou LR and Hernández PS. Design of an HACCP program for a cocoa processing facility. Archivos latinoamericanos de nutricion. 2012; 62(4) : 355-362. https://pdfs.semanticscholar.org/a2e6/1d4alf93b2ce257c52c773de02162f5ecd58.pdf

13. Mortimore S and Wallace C. HACCP: A practical approach. Springer Science \& Business Media. 2013 
14. Quaye S. Development of a HACCP Plan for a Model Cold Pressed Virgin Coconut Oil Industry in Ghana Doctoral dissertation. 2018. http://hdl.handle.net/123456789/11605

15. Wentholt W, Dembélé ARK and Diallo M. Gender and agricultural research in Mali, IER. KIT Publishers. The Netherlands. 2001 ; p. 141. Google Scholar

16. Wallace CA, Powell SC, Holyoak L. Development of methods for standardized HACCP assessment. British Food Journal. $2005 ; 107$ (10), 723-742. DOI: 10.1108/00070700510623513

17. Ryu K, Park KH, Yang JY and Bahk GJ. Simple approach in HACCP for evaluating the risk level of hazards using probability distributions. Food control. 2013; 30 (2), 459-462.13. DOI: 10.1016/j.foodcont.2012.07.042

18. Tadić D, Stefanović M and Milanović D. Fuzzy approach in evaluation of operations in food production. International Journal for Quality Research. 2007; 1(2): 97-104. http://ijqr.net/journal/v1-n2/2.pdf

19. Dzwolak W. HACCP in small food businesses. The Polish experience. Food control. 2014; 36(1): 132-137.17. DOI : 10.1016/j.foodcont.2013.07.043

20. Omer HMA. Implementing the Hazard Analysis Critical Control Points (HACCP) System in Fish Markets in Khartoum State, Sudan. Doctoral dissertation, Sudan University of Science \& Technology. 2017; 65p URI: http://repository.sustech.edu/handle/123456789/18494

21. Pierson MD. HACCP: principles and applications. Springer Science \& Business Media. 2012; p. 212, eBook ISBN 978-1-4684-8818-0. https://books.google.com/books?hl=fr\&lr=\&id=8-_iBwAAQBAJ\&oi=fnd\&pg=PRg\&dq=.+HACCP:+principles+and+applications\&ots=D7j3_dFVHF\&sig=GrrFZSzekOsVBZ1QRDBC11QSGs

22. DeBeer J, Nolte F, Lord CW, Colley J and Weddig L. Setting HACCP critical limits for the precooking PCC of commercially processed tuna. Food Protection Trends. 2017; 37 (3): 176-188.24. https://www.foodprotection.org/files/food-protection-trends/may-jun-17debeer.pdf

23. Al-Busaidi MA, Jukes D. J and Bose S. Hazard analysis and critical control point (HACCP) in seafood processing: An analysis of its application and use in regulation in the Sultanate of Oman. Food control. 2017; 73: 900-915. DOI: https://doi.org/10.1016/j.foodcont.2016.09.042 Available at http://centaur.reading.ac.uk/67639/.

24. FAO. General Principles of Food Hygiene. pp._201129. www.fao.org/input/download/standards/23/CXP_o0le.pdf.

25. Bimbenet JJ Duquenoy A and Trystram G. Food process engineering. From the basics to the applications. 2007. Dunod, Paris. pp. 567https://www.amazon.fr/G\%C3\%Agnie-proc\%C3\%Agd\%C3\%A9s-alimentaires-bases-applications/dp/2100763695

26. Quittet C and Nelis H. HACCP for SMEs and craftsmen. Dairy products sector. Presses agronomic of Gembloux, Belgium.1999; $494 \mathrm{p}$.

27. Burstyn I, Kromhout H, Cruise PJ and Brennan P. Designing an international industrial hygiene database of exposures among workers in the asphalt industry. The Annals of occupational hygiene. 2000; 44 (1): 57-66. DOI: 10.1093/annhyg/44.1.57

28. Ndiaye NA, Cisse M, Bonne R, Sene B, Kane NC and Montet D. Application of a facilitating HACCP system using two innovative methods for the production of Hibiscus sabdariffa by a Senegalese small and medium business (SMBs). International Food Research Journal. 2018, 25 (1): 376-682. http://www.ifrj.upm.edu.my/volume-25-2018.html

29. Codex Alimentarius - CAC/RCP 1. The International Code Recommended Practice - General Principles of Food Hygiene. 2003. http://www.codexalimentarius.nsset/ download/standards/23/CXP 001f.pdf.

30. Surak JG. HACCP and ISO development of a food safety management standard. 2003. Department of Science and Human Nutrition, 224. Poole Agricultural Center Clemson University Clemson, SC 29634-0371. 6p. https://elsmar.com/pdf_files/ISO\%2022000/surak_paper.pdf

31. Ndungu TW, Omwamba M, Muliro PS and Oosterwijk G: Hygienic practices and critical control points along the collection chains in smallholder collection and bulking enterprises in Nakuru and Nyandarua Countries, Kenya. African Journal of Food Science. 2016; 10 (11): 327-339. https://academicjournals.org/journal/AJFS/article-full-text-pdf/5CC7E9560924

32. Sikora T and Nowicki P. Food safety assurance according to Codex alimentarius and ISO 22000 Standard. Polish Journal of Food and Nutrition Sciences. 2007; 57(4): 489-493. http://journal.pan.olsztyn.pl/FOOD-SAFETY-ASSURANCE-ACCORDING-TO-CODEXALIMENTARIUS-AND-ISO-22000-STANDARD,98859,0,2.html

33. Mouffok N, Benhadja L, Ferhat $\mathrm{Z}$ and Bousbia. Identification and analysis of the dangers of a processed cheese process according to ISO 22 00. Qualita, Compiègne. 2013. https://hal.archives-ouvertes.fr/hal-00823126/document

34. Bonne RL. Presentation of two original methods to facilitate in the IAA implementation of best practices and hygiene manufacturing and method of haccp, as defined by the codex alimentarius. France, Toulouse: Paul Sabatier University, PhD Thesis. 2013; 132pp http://thesesups.ups-tlse.fr/2161/1/2013TOU30238.pdf 